\title{
KAJIAN BENCANA ANGIN RIBUT DI INDONESIA PERIODE 1990-2011: UPAYA MITIGASI BENCANA
}

\author{
Oleh: \\ Emilya Nurjani, Arum Rahayu, Febriyan Rachmawati \\ Jurusan Geografi Lingkungan Fakultas Geografi Universitas Gadjah Mada \\ n_emilya@geo.ugm.ac.id
}

\begin{abstract}
Abstrak
Tulisan ini bertujuan untuk mengkaji kejadian bencana angin ribut di Indonesia. Data yang digunakan adalah data kejadian angin ribut di Indonesia periode 1990-2011 dari BNPB. Data diolah statistik deskriptif dan dilakukan analisis spasial. Pemetaan secara spasial akan memudahkan dalam menganalisis distribusi dan kecenderungan lokasi terjadinya angin ribut setiap tahunnya dan mengetahui daerah-daerah di Indonesia yang memiliki kejadian bencana angin ribut tertinggi. Angin ribut banyak terjadi di Pulau Jawa.Provinsi Jawa Tengah merupakan daerah dengan kejadian angin ribut terbanyak (393 - 490 kejadian), sedangkan Provinsi Bengkulu dan Papua Barat tidak terjadi angin ribut (nol kejadian).Jumlah kerusakan bangunan terbanyak akibat angin puting beliung tahun 1990-2011 terjadi di Provinsi Jawa Tengah, sedangkan jumlah korban jiwa terbanyak terjadi di Provinsi Jawa Barat.Upaya mitigasi bencana dapat diutamakan pada daerah-daerah yang rawan akan bencana tersebut. Mitigasi bencana akan mengurangi dampak buruk dari bencana angin ribut, sehingga kerugian akan kerusakan dari element at risk karena bencana angin ribut dapat diminimalisasi besarnya.
\end{abstract}

Kata Kunci : angin ribut, mitigasi bencana, kajian

\section{STUDY OF WINDSTORM DISASTERS IN INDONESIA DURING 1990-2011: A DISASTER MITIGATION}

\begin{abstract}
$\underline{\text { Abstract }}$
This paper aims to assess the incidence of hurricanewindstorm disasters in Indonesia. Data used include data windstorm events in Indonesia during 1990-2011 from $B N P B$. Data processed descriptive statistics and spatial analysis. Spatially mapping will facilitate in analyzing the distribution and location of the occurrence trend of hurricanes each year and know the areas in Indonesia, which has the highest incidence of catastrophic hurricanes. Many windstorm occur in Java. Central Java was the region with the highest incidence of windstorm (393-490 events), while the provinces of Bengkulu and West Papua hurricanes do not occur (zero incidence). Highest number of building damage due to a windstorm in 1990-2011 occurred in Central Java Province, while the highest number of fatalities occurred in the West Java Province. Disaster mitigation efforts can be prioritized in areas prone to such disasters. Disaster mitigation will reduce the adverse effects of the hurricane disaster, so the loss will damage the elements at risk for hurricane disaster can be minimized magnitude.
\end{abstract}

Keywords :Windstorm, Disaster Mitigation, Assessment

\section{Pendahuluan}

Angin merupakan gerak udara yang sejajar dengan permukaan bumi (Tjasyono, 2004). Bergeraknya angin dipengaruhi oleh faktor pendorong yaitu perbedaan tekanan 
udara antara satu tempat dengan tempat lain. Angin selalu bertiup dari tempat bertekanan tinggi ke tempat yang bertekanan lebih rendah.Angin dapat bergerak secara vertikal dengan kecepatan yang berfluktuasi dan bervariasi. Angin bergerak secara berkelok-kelok sesuai medan yang yang dilaluinya. Pergerakan angin yang cepat terjadi jika resistensi media yang dilewatinya lebih rendah.

Angin berkecepatan tinggi terjadi karena adanya perbedaan tekanan yang sangat besar antara 2 lokasi yang berdekatan.Angin tersebut disebut pula angin ribut yang karena kecepatannya dapat menimbulkan daya rusak terhadap berbagai media yang dilaluinya. Dalam skala Beaufort, yang disebut angin ribut ialah angin mulai skala 6 yaitu angin berkecepatan 10,8-13,8 $\mathrm{m} /$ detik. Terjadinya angin ribut dipengaruhi pembentukan awan Cumulunimbus dari konveksi maupun orografi massa udara yang tidak stabil atau dari adveksi massa udara relatif dingin dengan massa udara yang relatif panas dalam frontal massa udara (Nirkaryanto, 1979). Keadaan tersebut menyebabkan posisi konvergensi dan divergensi mempunyai perbedaan tekanan udara yang sangat besar pada posisi yang berdekatan sehingga memicu terjadinya angin ribut.

Pemanasan global menyebabkan terjadinya perubahan iklim yang berdampak pada fenomena-fenomena iklim yang tidak lazim terjadi, seperti pergerakan angin.Salah satu fenomena yang disebabkan karena adanya perubahan iklim adalah kejadian angin ribut.Angin tersebut juga mempunyai arah yang tidak beraturan. Kecepatan angin ribut lebih dari $95 \mathrm{~km}$ per jam, sehingga berpotensi menyebabkan kerusakan dalam segala bentuk budi daya yang ada di permukaan bumi, seperti rusaknya permukiman, sektor pertanian, dan sarana dan prasarana umum. Kerugian yang ditimbulkan oleh adanya angin ribut tersebut sebagian besar dalam sektor sosial ekonomi.

Kondisi geografis di Indonesia yang merupakan daerah tropis sangat mendukung terjadinya angin ribut karena dilihat dari letak lintang dan bujurnya. Indonesia merupakan daerah tropis yang memiliki kelembaban di atas $75 \%$ yang menyebabkan ketidakstabilan massa udara. Letak Indonesia yang berbatasan langsung dengan Samudera Hindia dan Samudera Pasifik serta dekat dengan Benua Asia dan Australia juga mempengaruhi terjadinya angin ribut.Adanya Angin Monsun Barat dan Angin Monsun Timur memicu terjadinya angin ribut di daratan.Angin ribut banyak terjadi pada musim penghujan, namun tidak menutup kemingkinan angin ribut terjadi di saat musim kemarau.

Informasi mengenai kejadian angin ribut umumnya meliputi daerah kejadian (kabupaten atau kecamatan), waktu kejadian dan dampak kerugian yang ditimbulkan.Informasi kejadian angin ribut tersebut digunakan untuk membuat peta persebaran kejadian angin ribut secara spasial di Indonesia. Hasil pengolahan informasi tersebut dapat memberikan gambaran daerah yang rawan bencana angin ribut di Indonesia.Selain informasi tersebut di atas, informasi kejadian angin ribut juga berisi frekuensi waktu kejadiannya.Frekuensi kejadian angin ribut digunakan untuk mengetahui waktu kapan saja angin ribut terjadi.Informasi mengenai dampak kejadian angin ribut perlu diperhatikan untuk mengetahui seberapa besar kerugian yang terjadi di daerah kejadian.Dampak kerugian tersebut meliputi kerugian secara material dan non material yang ditanggung oleh individu dan pemerintah.

Bencana menurut UU No. 24 Tahun 2007 ialah rangkaian peristiwa yang mengancam dan mengganggu kehidupan dan penghidupan masyarakat yang disebabkan, baik oleh faktor alam dan/atau faktor non alam maupun faktor manusia sehingga mengakibatkan timbulnya korban jiwa manusia, kerusakan lingkungan, kerugian harta benda, dan dampak psikologis. Bencana dapat dikaitkan dengan kerusakan, kerugian, kehilangan jiwa dan kehidupan atau keminduran nilai sosial ekonomi yang disebabkan oleh kejadian alam.Bencana dapat dikategorikan menjadi 3 
macam yaitu bencana alam, bencana non alam dan bencana sosial.Bencana angin ribut merupkan bencana alam yang terjadi secara alami tanpa intervensi manusia sebagai penyebabnya.

Manajemen bencana ialah serangkaian upaya yang meliputi penetapan ke bijakan pembangunan yang berisiko timbulnya bencana, kegiatan pencegahan bencana, tanggap darurat, dan rehabilitasi.Dalam manajemen bencana terdapat banyak istilah yang berkaitan dengan kebencanaan, seperti rawan bencana (vulnerability), risiko (risk) dan elemen at risk. Rawan bencana ialah kondisi atau karakteristik geologis, biologis, hidrologis, klimatologis, geografis, sosial, budaya, politik, ekonomi, dan teknologi pada suatu wilayah untuk jangka waktu tertentu yang mengurangi kemampuan mencegah, meredam mencapai kesiapan, dan mengurangi kemampuan untuk menanggapi dampak buruk bahaya tertentu (UU No. 24 Tahun 2007). Risiko merupakan potensi kerugian yang ditimbulkan akibat bencana pada suatu wilayah dan kurun waktu tertentu.Elemen at risk dalam kaitannya dengan bencana merupakan segala sesuatu yang berisiko terkena bencana sehingga dapat mengalami kerusakan meliputi: orang, infrastruktur, hasil panen, dan kendaraan.

Konsep mitigasi bencana ialah serangkaian upaya untuk mengurangi akibat-akibat yang ditimbulkan oleh adanya bencana dengan melalui pembangunan fisik, penyadaran terhadap masyarakat dan peningkatan kemampuan menghadapi ancaman bencana.Mitigasi bencana merupakan istilah yang menunjuk pada semua kegiatan/ tndakan untuk mengurangi risiko bencana, yang dapat dilakukan sebelum bencana tersebut terjadi. Mitigasi bencana mencakup perencanaan dan pelaksanaan berbagi tindakan pengurangan risiko bencana serta proses perencanaan untuk respon yang efektif dalam menghadapi bencana. Tindakan pengurangan risiko bencana tersebut bertujuan untuk mengurangi dampak kerugian yang ditimbulkan akibat bencana dengan menghilangkan kerentanan terhadap bencana.

Kejadian angin ribut hingga tahun ini sudah banyak terjadi di berbagai daerah di Indonesia.Kejadian angin ribut menyebabkan kerusakan bangunan rumah, fasilitas umum dan infrastruktur dan menyebabkan tumbangnya pohon.Untuk mengetahui sebaran dan frekuensi kejadian angin ribut di Indonesia diperlukan data yang telah tercatat di suatu instansi seperti BNPB ataupun BPBD. Data tersebut dapat disajikan dalam bentuk tabulasi, grafik ataupun peta untuk mengetahui daerah-daerah di Indonesia yang memiliki kejadian bencana angin ribut tertinggi sehingga upaya mitigasi bencana dapat diutamakan pada daerah-daerah yang rawan akan bencana tersebut.

Tujuan dari tulisan ini antara lain 1) melakukan pemetaan kejadian bencana angin ribut dan mengetahui daerah-daerah yang memiliki intensitas kejadian bencana angin ribut yang tinggi di Indonesia pada periode 1990-2011; 2) mengetahui dampak-dampak yang disebabkan oleh bencana angin ribut terhadap elemen at risk bencana angin ribut; 3) memberikan informasi kejadian angin ribut yang pernah terjadi di Indonesia secara spasial dan temporal periode 1990-2011; dan 4)menentukan langkah-langkah mitigasi bencana angin ribut yang tepat untuk daerah-daerah yang berintensitas kejadian tinggi.

\section{Metodologi}

Alat yang digunakan adalah seperangkat computer dengan software pengolah data (Microsoft Excel), software pembuatan laporan (Microsoft Word) dan software untuk membuat peta (ArcGis 9.3). Bahan yang digunakan adalah peta dasar digital Indonesia, data angin (kecepatan dan arah) se-Indonesia, data suhu se-Indonesia tahun 2006, 2007 dan 2008, data jumlah penduduk menurut provinsi se-Indonesia tahun 1990, 1995, 2000, 2005 dan 2010, data kejadian angin ribut di seluruh Indonesia tahun 1990-2011, data kejadian angin ribut di seluruh Indonesia 1 tahun terakhir (Oktober 2011-September 
2012), data digital penggunaan lahan berdasar peta Rupa Bumi Indonesia, dan data digital penggunaan lahan se-Jawa.

Data kejadian bencana angin puting beliung diperoleh dari publikasi data melalui media informasi (internet) dalam http://dibi.bnpb.go.id.Data jumlah penduduk, data angindan data suhu diperoleh dari publikasi data oleh instansi terkait yaitu Badan Pusat Statistik (BPS) dan Badan Meteorologi Klimatologi dan Geofisika (BMKG) serta dari hasil penelitian lain. Data digital untuk pembuatan peta diperoleh dari Bakosurtanal dan PUSPICS UGM. Informasi dan referensiuntuk keperluan analisis data dan pembahasan diperoleh dari hasil studi pustaka, media informasi (internet), serta wawancara mendalam (in depth interview) ke BPBD Kabupaten Sleman.Dokumentasi kerusakan akibat angin ribut diperoleh dari kunjungan langsung ke lokasi kejadian bencana (Kecamatan Kalasan, Sleman) dan dokumentasi oleh BPBD Kabupaten Sleman.

Awal proses pengolahan data ialah komputasi data-data sekunder dengan program Ms. Excel untuk melakukan analisis temporal mengenai tren data yang diolah (membuat grafik dan tabel).Pembuatan basis data (database) kejadian angin ribut di Indonesia yang berisi waktu (jam, bula dan tahun), lokasi (provinsi) dan dampak kejadian (korban jiwa, kerusakan dan kerugian) yang ditimbulkan.Pembuatan peta distribusi kejadian angin ribut di Indonesia tahun 1990-2011 dengan program ArcGIS 9.3.Penyalinan peta penggunaan lahan Jawa dengan ArcGIS 9.3.

Adapun analisis yang dilakukan meliputi :

1. Analisis Frekuensi Bencana Angin Ribut

Analisis frekuensi angin ribut menggunakan unit wilayah provinsi dengan data yang digunakan ialah hasil pencatatan data kejadian bencana angin ribut dari setiap kabupaten yang ada di Indonesia. Analisis dilakukan dengan melihat trendata kejadian setiap tahun yaitu dari tahun 1990 hingga tahun 2011 pada data disajikan dalam bentuk tabel, grafik batang dan kurva. Analisis untuk melihat akumulasi kejadian terbanyak dengan membuat grafik kejadian menurut provinsi yang ada di Indonesia. Kemudian untuk melakukan analisis frekuensi angin ribut secara keruangandengan pembuatan peta distribusi angin ribut se-Indonesia.

2. Analisis Penyebab Terjadinya Bencana Angin Ribut

Analisis dilakukan dengan mengkaitkan faktor letak geografis daerah penelitian, kondisi topografi, penggunaan lahan, pertambahan jumlah penduduk serta waktu kejadian dengan kecenderungan kejadian angin ribut.

3. Analisis Time Series Kejadian Bencana Angin Ribut

Analisis dilakukan dengan membuat grafik kejadian menurut waktu bulanan dan kecenderungan jam-jam kejadian. Penyajian data kejadian menurut waktu bulanan dapat digunakan untuk melihat tren bulan-bulan mana saja yang memiliki jumlah kejadian relatif besar.

4.

Analisis Dampak Bencana Angin Ribut

Analisis dampak dilakukan dengan membuat grafik dan tabel yang menyajikan jumlah korban jiwa dan kerusakan akibat bencana angin ribut. Dengan menggunakan grafik dan tabel, maka dapat diketahui provinsi-provinsi dan pulau-pulau mana saja yang mengalami bencana angin ribut tertinggi dan terendah.Penilaian besarnya kerusakan dan kerugian dimaksudkan untuk mengukur skala dampak bencana yang terjadi sehingga dapat menentukan prioritas penanganan bencana dan akhirnya dapat menentukan strategi rekonstruksi dan rehabilitasi pasca bencana.Setiap rumah dihargai dengan nilai Rp 25.000.000,00 per unit. Rumah rusak berat dinilai dengan harga $100 \%$ dari harga rumah, sedangkan rumah rusak ringan seharga 30\% dari harga rumah. Fasilitas kesehatan diasumsikan seluas $300 \mathrm{~m}^{2}$ dengan harga $\mathrm{Rp} 3.000 .000,00$ 
per $\mathrm{m}^{2}$. Fasilitas pendidikan diasumsikan seluas $500 \mathrm{~m}^{2}$ dengan harga $\mathrm{Rp} 3.000 .000,00$ per $\mathrm{m}^{2}$.

5 .

Strategi dalam melakukan mitigasi bencana dilakukan dengan melihat daerah-daerah mana saja yang rawan akan bencana angin ribut. Daerah yang memiliki jumlah kejadian bencana relatif banyak menjadi prioritas utama dalam upaya mitigasi. Mitigasi dilakukan dengan mempertimbangkan jumlah korban, kerusakan dan kerugian yang ditimbulkan. Strategi dalam upaya mitigasi bencana akan dibuat disetiap tahap dalam managemen kebencanaan yaitu pada saat sebelum terjadi bencana, saat terjadi bencana dan pemulihan kembali pasca bencana.

\section{Hasil dan Pembahasan}

Kondisi geografis di Indonesia yang merupakan daerah tropis sangat mendukung terjadinya angin ribut. Indonesia memiliki kelembapan di atas $75 \%$ yang menyebabkan ketidakstabilan massa udara. Indonesia sebagai negara kepulauan dikelilingi oleh lautan seperti Samudera Hindia dan Samudera Pasifik serta berdekatan dengan Benua Asia dan Australia juga mempengaruhi terjadinya angin ribut. Adanya angin monsun barat dan angin monsun timur memicu terjadinya angin ribut di daratan.Angin ribut banyak terjadi pada musim penghujan, namun tidak menutup kemingkinan angin ribut terjadi di saat musim kemarau ataupun transisi antara kedua musim tersebut.

Bencana angin ribut yang dicatat oleh BNPB merupakan jenis bencana angin puting beliung yaitu sebutan untuk angin kencang di tanah Jawa. Jumlah kejadian bencana angin ribut yang tercatat, terus mengalami peningkatan dari tahun ke tahun seperti yang tercatat pada tahun 1990-2011 (Gambar 1).Pada tahun 1990 hingga 1997 sebagian besar data bernilai nol kejadiankarena pada tahun-tahun tersebut belum banyak obyek-obyek bencana (element at risk) yang mengalami kerusakan sehingga kejadian bencana angin ribut belum begitu diperhatikan oleh masyarakat dan pihak terkait. Selain itu, masih terbatasnya ilmu pengetahuan dan teknologi sehingga masih sedikit pencatatan berita dan publikasi bencana baik dari surat kabar maupun media massa lainnya.Pada tahun 1997 hingga 2007 hanya sedikit saja kejadian bencana yang dicatat namun jumlahnya sudah terus meningkat dari tahun ke tahun. Peningkatan ini menunjukan bahwa sudah mulai ada perhatian dari pemerintah terkait dengan kejadian bencana angin ribut. Pencatatan terus meningkat karena kerugian yang ditimbulkan akibat bencana tersebut terus meluas dan meningkat jumlahnya. Tahun 2008 hingga tahun 2009 mengalami kenaikan jumlah kejadian lebih dari 100\% yaitu dari 166 kejadian menjadi 340 kejadian. $\mathrm{Hal}$ ini karena sistem pendataan bencana sudah semakin baik dan juga monitoring cuaca dengan satelit terus dimanfaatkan. Kemudian dari tahun 2009 hingga 2011menunjukan trendnaik. Jumlah bencana angin kencang terus meningkat jumlahnya karena adanya kerusakan lingkungan yang mempengaruhi perubahan iklim global. Hal ini disebabkan oleh jumlah penduduk yang terus meningkat, perubahan penggunaan lahan dan kemajuan teknologi.

Distribusi bencana angin ribut banyak terjadi di beberapa provinsi yang ada di Pulau Jawa yaitu Provinsi Jawa Barat, Jawa Tengah dan Jawa Timur.Pada peta distribusi angin ribut (Gambar 2)tampak bahwa kelas kejadian angin ribut di ketiga provinsi tersebut termasuk dalam kelas I hingga III. Provinsi Jawa Tengah termasuk dalam Kelas I (393 - 490 kejadian), Jawa Timur dan Jawa Barat termasuk dalam Kelas III (197 - 294 kejadian). sedangkan di Provinsi DKI jakarta, Banten dan DI Yogyakarta tergolong Kelas V, dimana jumlah kejadiannya relatif kecil yaitu berkisar antara 1 - 98 kejadian. Jumlah kejadian (frekuensi) bencana angin ribut yang paling banyak terjadi adalah di Provinsi Jawa Tengah yaitu sebanyak 488 kejadian. Provinsi yang tidak terjadi bencana angin ribut 
(nol kejadian) yaitu Provinsi bengkulu dan Papua Barat. Indonesia bagian timur yang memiliki frekuensi angin ribut relatif tinggi yaitu Nusa Tenggara Timur 112 kejadian, Sulawesi Tenggara 96 kejadian, Sulawesi selatan juga sebanyak 96 kejadian dan provinsi lainnya relatif kecil.

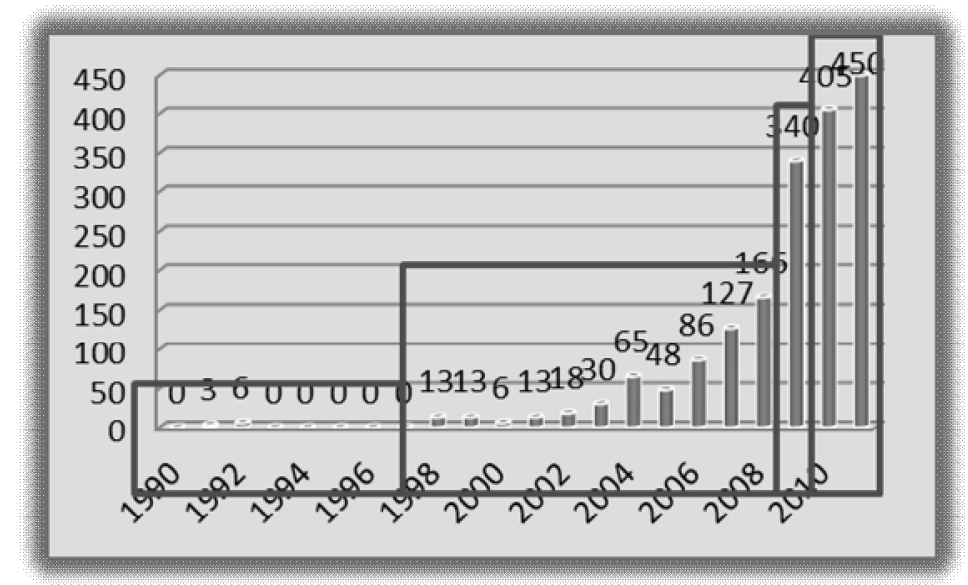

Gambar 1. Grafik Jumlah Kejadian Bencana Angin Ribut Tahun 1990 - 2011

(Sumber : Pengolahan Data Sekunder dari BNPB, 1990 - 2011, http://dibi.bnpb.go.id)

Berdasarkan data jumlah kejadian bencana angin ribut tahun 1990-2011, dapat diketahui bahwa beberapa provinsi di Pulau Jawa memiliki jumlah kejadian yang relatif lebih banyak dibanding di luar Jawa. Hal ini karena Pulau Jawa dikelilingi oleh lautan seperti Lautan Hindia, Laut Jawa, Laut Natuna dan Selat Malaka dan juga adanya dataran yang letaknya berdekatan dengan Jawa yaitu Pulau Sumatera dan Benua Australia. Sehingga arus angin yang berasal dari wilayah-wilayah tersebut mempunyai perbedaan suhu, tekanan dan kelembapan yang relatif tinggi.Kondisi topografi Pulau Jawa yang heterogen yaitu banyak terdapat perbukitan, pegunungan, lembah serta daerah dataran memungkinkan adanya daerah-daerah yang lembab maupun kurang lembab. Tempattempat angin naik (orografi) memiliki rata-rata kelembapan yang relatif tinggi dibanding tempat-tempat angin turun. Pada daerah bertopografi yang heterogen memungkinkan terjadinya perbedaan suhu yang tinggi yang akan mempengaruhi gerakan angin sehingga menyebabkan terjadinya pertemuan antar jenis angin yang menimbulkan adveksi (pemanasan horisontal) seperti adveksi antara angin celah dan angin turun, adveksi antara angin turun dan angin lembah. Melalui celah-celah pegunungan hingga pada dataran rendah tersebutlah awal mula terjadinya adveksi front dingin yang kebanyakan menimbulkan angin ribut di tempat bergunung seperti di Jawa.Pergerakan angin dipengaruhi oleh kondisi kekasaran permukaan suatu wilayah terkait dengan gaya gesekan. Gaya gesekan yang besar menyebabkan pergerakan angin melemah.Pada daerah yang permukaannya datar dan halus memiliki gaya gesek lemah, maka kecepatan angin akan besar. Oleh karena itu angin kencang sering terjadi pada daerah dataran dan pesisir seperti topografi pada Provinsi Jawa Tengah bagian utara dan selatan yang memiliki topografi dengan permukaan yang relatif lebih halus dibanding bagian tengah.

Badan Nasional Penanggulangan Bencana (BNPB)telah menginformasikan bahwa 1 tahun terakhir ini yaitu dari Bulan Agustus 2011 hingga Bulan November 2012, bencana angin ribut terjadi sebanyak 176 kejadian yang menyebar di seluruh Indonesia. Dimana frekuensi angin ribut sebagian besar terjadi di Pulau Jawa yaitu Provinsi Jawa Barat, Jawa Tengah dan Jawa Timur. Berdasarkan Gambar 3, dapat diketahui bahwa sebagian besar kejadian terjadi pada waktu siang hingga menjelang sore yaitu pada pukul 12.00 sampai pukul 16.00. Suhu pada jam-jam inilah yang biasanya tercatat sebagai suhu maksimum 
rata-rata harian. Pada rentang waktu tersebut suhu tercatat lebih tinggi dibandingkan rentang waktu lainnya. Suhu maksimum merupakan salah satu faktor penyebab terjadinya angin ribut. Dimana pemanasan atau semakin tingginya suhu di suatu tempat akan mendorong terjadinya konveksi. 


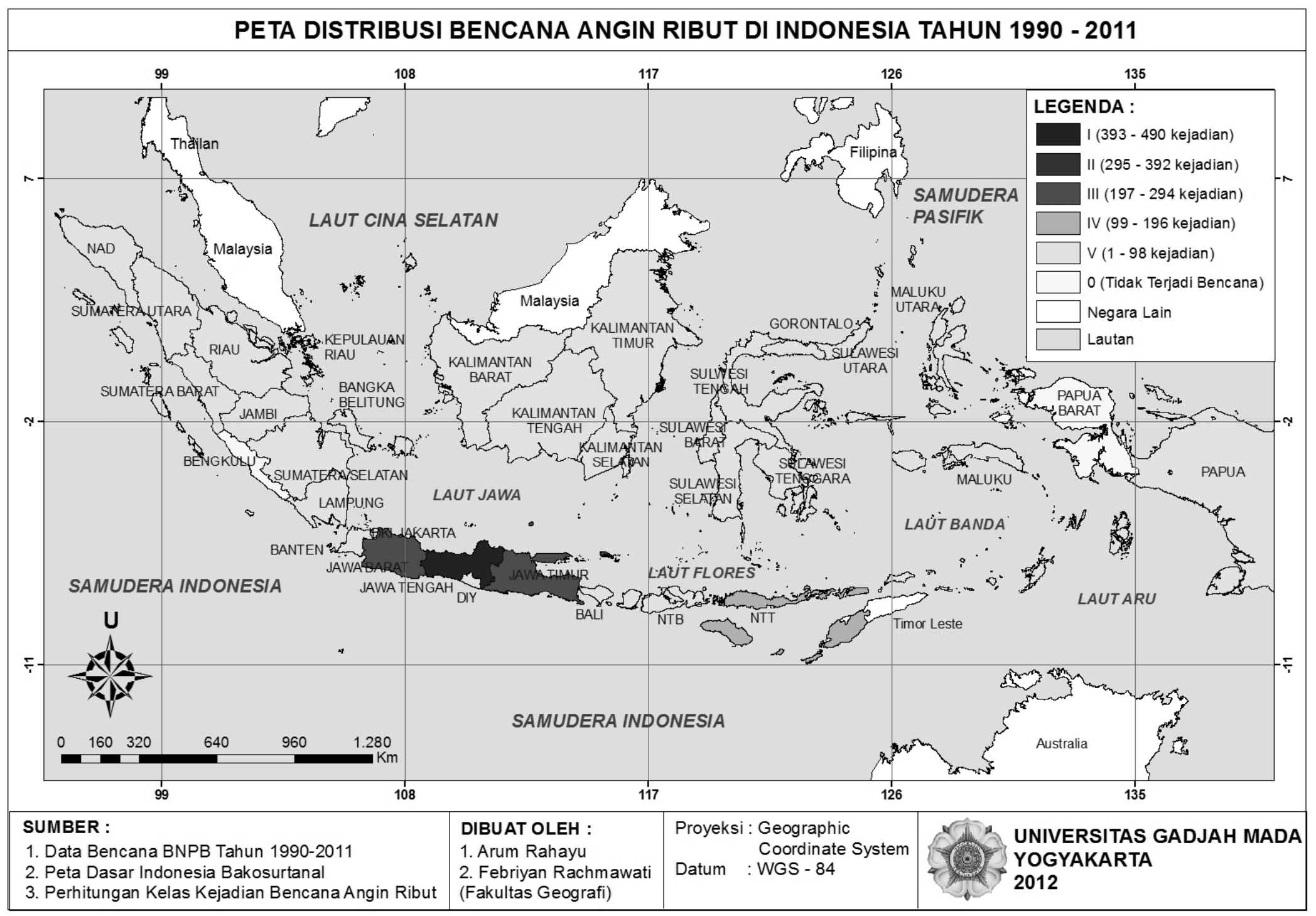

Gambar 2. Peta Distribusi Bencana Angin Ribut di Indonesia Tahun 1990-2011 
Berdasarkan data kejadian angin ribut 2011 - 2012 (1 tahun terakhir) dapat diketahui bahwa angin ribut banyak terjadi pada Bulan Oktober hingga Maret.Bulanbulan yang mengalami banyak kejadian bencana angin ribut tersebut merupakan bulanbulan saat terjadinya musim hujan di Indonesia yaitu pada Bulan Oktober-April.Dimana biasanya kejadian angin ribut disertai dengan hujan lebat dan petir yang menjadi ciri khas fenomena di musim hujan.Angin ribut juga banyak terjadi pada musim Pancaroba atau transisi antara dua musim yaitu trasnsisi antara musim hujan ke musim kemarau atau sebaliknya.Frekuensi angin ribut yang tinggi terjadi pada Bulan Oktober-Desember (transisi musim kemarau ke musim hujan) dan Maret-April (transisi musim hujan ke musim kemarau).Pada musim Pancaroba posisi zona konvergensi antar tropik berkisar diatas ekuator sehingga mengalami variabilitas suhu tertinggi yang memicu terjadinya pergerakan angin yang kencang (Nirkaryanto, 1979).Pada Bulan April terus mengalami penurunan jumlah kejadian bencana angin ribut hingga Bulan Juli, kemudian mengalami tren naik kembali pada Bulan Juli-September karena sedang terjadi musim kemarau di Indonesia.

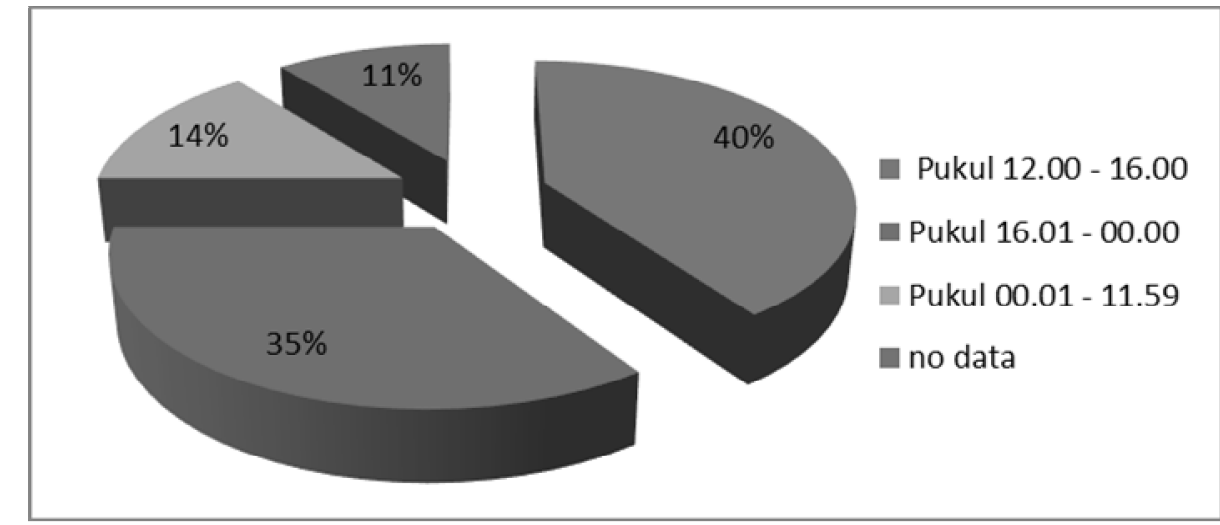

Gambar 3. Persentase Frekuensi Angin Ribut 1 Tahun Terakhir (Tahun 2011-2012) menurut Waktu dalam 24 Jam

(Sumber : Pengolahan Data Sekunder dari BNPB 2011 - 2012, http://dibi.bnpb.go.id)

Banyaknya kejadian bencana angin ribut di Indonesia dipengaruhi oleh penggunaan lahan yang ada.Penggunaan lahan berupa permukiman kota, perkampungan dan keberadaan gedung-gedung sebagai akibat dari pertambahan penduduk. Hal ini akan mempengaruhi kondisi suhu udara, dimana tekanan dan kelembapan udara akan meningkat pula. Hal inilah yang memicu terjadinya angin ribut. Jumlah penduduk yang terus meningkat akan mempengaruhi perubahan penggunaan lahan. Jumlah penduduk di Pulau Jawa memiliki jumlah penduduk yang relatif tinggi dibandingkan provinsi lainnya.Jumlah penduduk Jawa Barat, Jawa Tengah dan Jawa Timur mencapai puluhan juta jiwa setiap tahunnya dan terus meningkat jumlahnya. Jumlah kejadian bencana angin ribut di Pulau Jawa relatif tinggi.Provinsi Jawa Tengah memiliki penggunaan lahan yang lebih halus jika dilihat dari kekasaran penggunaan lahannya dibanding provinsi lain, dimana wilayahnya masih banyak terdapat sawah, perkebunan, tegalan dan sedikit permukiman pada Jawa Tengah bagian utara serta secara topografi banyak terdapat dataran. Hal ini akan memicu pergerakan angin yang kencang karena gaya gesekan angin dan permukaan lahan yang relatif kecil.

Bencana angin ribut menghantam apa saja yang dilewatinya seperti bangunan dan pepohonan. Dampak yang ditimbulkan akibat hantaman angin ribut biasanya ialah terbangnya atap rumah, tumbangnya pohon dan kerusakan dinding rumah.Angin ribut yang bertiup juga dapat merusak tiang-tiang listrik sehingga menyebabkan aliran listrik 
mati dan tiang-tiang dapat jatuh menimpa apapun yang ada di sekitarnya seperti kendaraan, rumah ataupun pohon.Angin ribut yang terjadi juga dapat menyebabkan adanya korban jiwa.Korban jiwa dapat disebabkan oleh terjangan angin ribut secara langsung atau tertimpa puing-puing dampak angin ribut.Korban jiwa dapat mengalami luka-luka atau bahkan meninggal akibat tertimpa puing-puing dampak angin ribut.Korban juga dapat hilang akibat tertimbun puing-puing bangunan.

Berdasarkan data kejadian bencana angin puting beliung di Indonesia selama periode 1990-2011, frekuensi kejadian bencana paling banyak terjadi di Provinsi Jawa Tengah.Banyaknya kejadian bencana angin puting beliung di Jawa Tengah berdampak pada banyaknya kerusakan bangunan.Selain itu juga mengakibatkan adanya korban jiwa yang mengalami luka-luka, meninggal, hilang ataupun mengungsi, namun jumlah korban jiwa yang terkena dampak akibat angin puting beliung di Jawa Tengah bukan yang paling banyak.Korban jiwa akibat angin puting beliung terbanyak terjadi di Provinsi Jawa Barat yaitu sejumlah 7492 jiwa.Bencana angin puting beliung yang tidak mengakibatkan adanya korban jiwa terjadi di Provinsi Bangka Belitung, Gorontalo, Kalimantan Tengah, Maluku, dan Sulawesi Barat.Jumlah korban jiwa terendah akibat bencana angin puting beliung terjadi di DKI Jakarta sebanyak 11 jiwa.Untuk korban meninggal terbanyak terdapat di Provinsi Jawa Tengah yaitu sebanyak 48 jiwa (Gambar 4).

Bencana bencana angin puting beliung tentunya tidak hanya menyebabkan adanya korban jiwa tetapi juga kerusakan.Kerusakan bangunan (rumah rusak ringan dan berat, fasilitas kesehatan dan fasilitas pendidikan) yang terjadi akibat bencana angin puting beliung terparah terjadi di Provinsi Jawa Tengah yaitu sebanyak 12.850 unit (Gambar 5). Hal tersebut karena frekuensi kejadian bencana angin puting beliung yang terjadi di Provinsi Jawa Tengah tinggi.Kerusakan bangunan akibat bencana angin puting beliung terendah terdapat di Provinsi Papua sebanyak 1 unit yaitu kerusakan fasilitas pendidikan.Bencana angin puting beliung tidak menyebabkan adanya kerusakan bangunan di Provinsi DKI Jakarta dan Gorontalo.Hal tersebut dapat terjadi karena frekuensi kejadian bencana angin puting beliung di kedua provinsi tersebut sedikit/ rendah.

Kerusakan bangunan yang terjadi akibat bencana angin puting beliung dapatdinilai secara ekonomi dengan menaksir nilai kerugian ke dalam nilai rupiah.Penelitian ini menilai kerugian akibat bencana angin puting beliung mengacu kepada taksiran kerugian dari kerusakan akibat bencana yang dilakukan oleh BNPB. Setiap rumah dihargai dengan nilai Rp 25.000.000,00 per unit. Rumah rusak berat dinilai dengan harga $100 \%$ dari harga rumah, sedangkan rumah rusak ringan seharga $30 \%$ dari harga rumah. Fasilitas kesehatan diasumsikan seluas $300 \mathrm{~m}^{2}$ dengan harga $\mathrm{Rp}$ $3.000 .000,00$ per $\mathrm{m}^{2}$. Fasilitas pendidikan diasumsikan seluas $500 \mathrm{~m}^{2}$ dengan harga $\mathrm{Rp}$ $3.000 .000,00$ per $\mathrm{m}^{2}$.

Frekuensi kejadian bencana angin puting beliung di Indonesia selama periode 1990-2011 paling banyak terjadi di Provinsi Jawa Tengah yang berdampak pada banyaknya kerusakan bangunan. Hal tersebut tentunya mengakibatkan adanya kerugian secara materi untuk proses pemulihan serta proses-proses lain dalam manajemen bencana. Kerusakan bangunan akibat bencana angin puting beliung di Jawa Tengah sebanyak 12.850 unit yang terdiri atas 4.844 unit rumah rusak berat, 7938 unit rumah rusak ringan, 3 unit kerusakan fasilitas kesehatan dan 65 unit kerusakan fasilitas pendidikan. Berdasrkan kerusakan bangunan yang terjadi, jumlah kerugian akibat bencana angin puting beliung yang terdapat di Jawa Tengah sebesar Rp 280.835.000.000,00 yang didominasi oleh kerugian dari rumah rusak berat. Kerugian terendah yang dialami akibat bencana angin puting beliung di Jawa Tengah ialah dari kerusakan fasilitas kesehatan. 


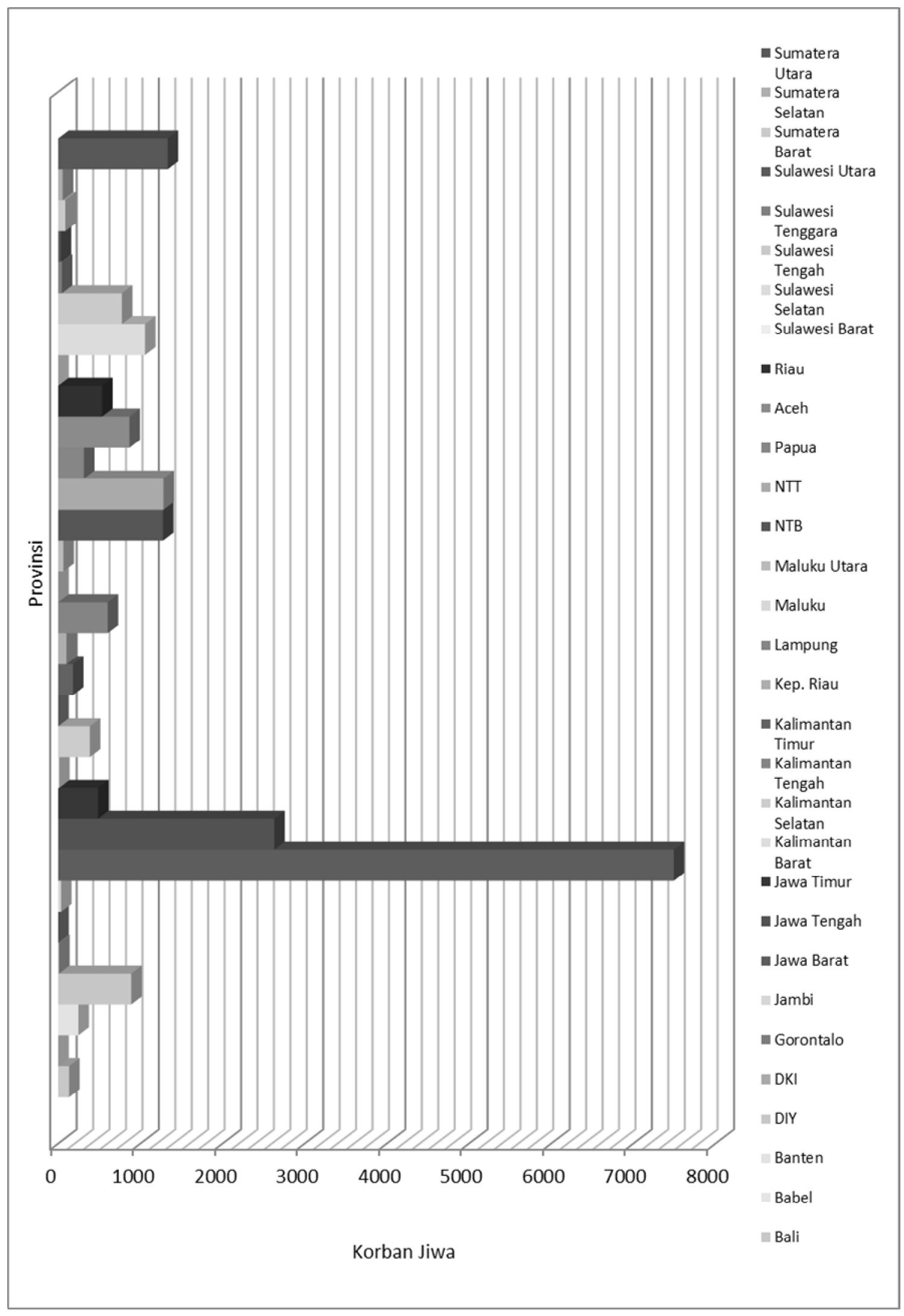

Gambar 4. Jumlah Korban Jiwa Akibat Bencana Angin Puting Beliung Menurut Provinsidi Indonesia Tahun 1990-2011

(Sumber : Pengolahan Data Sekunder dari BNPB 1990 - 2011, http://dibi.bnpb.go.id) 


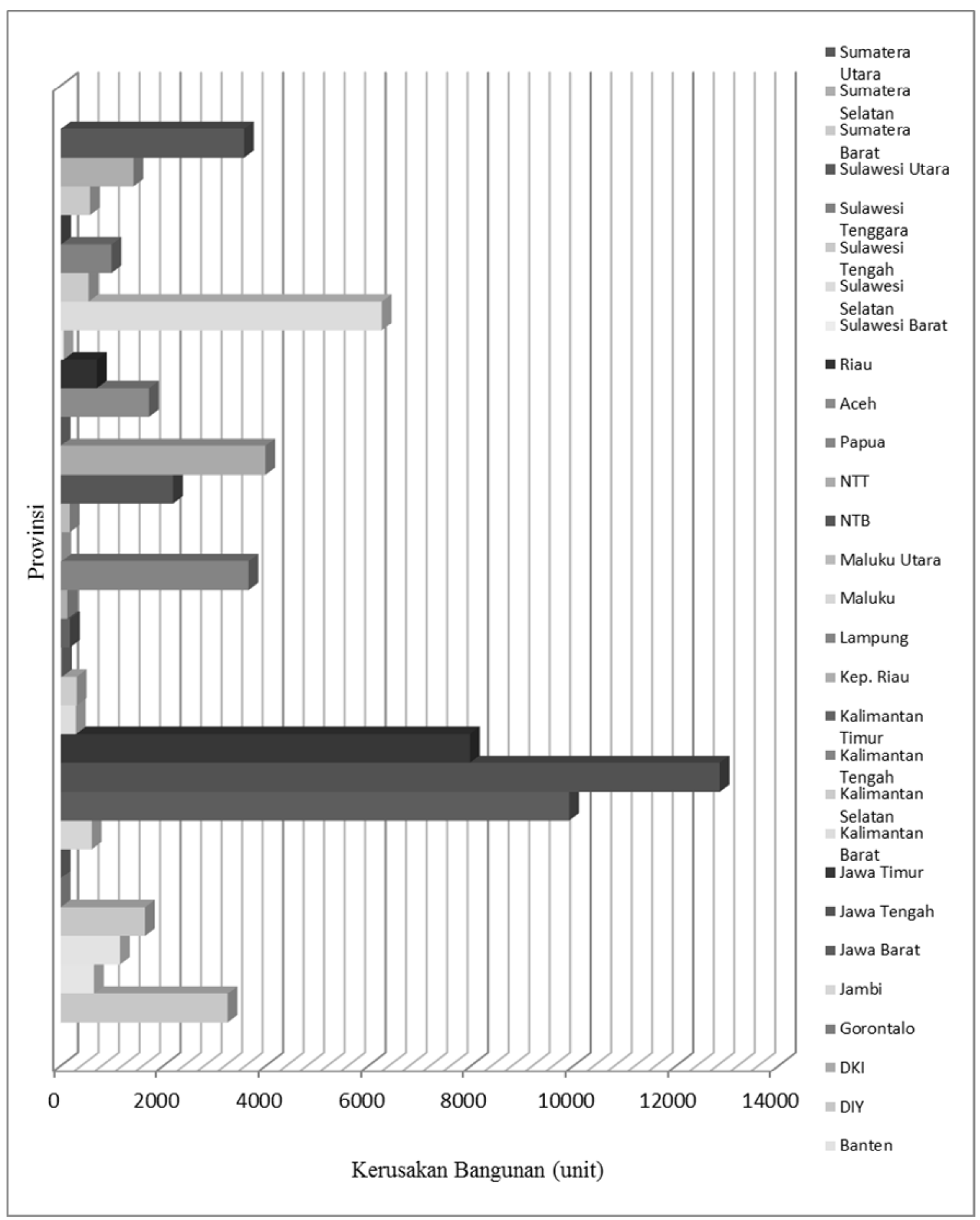

Gambar 5. Jumlah Kerusakan Bangunan Akibat Bencana Angin Puting Beliung Menurut Provinsidi Indonesia Tahun 1990-2011

(Sumber : Pengolahan Data Sekunder dari BNPB 1990 - 2011, http://dibi.bnpb.go.id) 
Penilaian kerugian akibat angin puting beliung menunjukan bahwa kerugian terendah yang ditimbulkan dari kerusakan bangunan akibat bencana angin puting beliung di Indonesia ialah di Provinsi Maluku yaitu sebesar Rp 245.000.000,00. Besarnya kerugian tersebut terdiri atas kerugian dari kerusakan rumah berskala berat yang bernilai Rp 200.000.000,00 dan kerusakan rumah berskala ringan sebesar $\mathrm{Rp} 45.000 .000,00$. Tidak ada kerugian dari fasilitas kesehatan dan pendidikan yang ditimbulkan oleh bencana angin puting beliung di Maluku. Di Provinsi Papua hanya terdapat kerusakan banguan fasilitas pendidikan akibat bencana angin puting beliung yang kerugiannya ditaksir sebesar Rp 1.500.000.000,00. Provinsi di Indonesia yang tidak terdapat kerusakan bangunan akibat bencana angin puting beliung ialah DKI Jakarta dan Gorontalo.Hal tersebut dapat terjadi karena intensitas kejadian bencana angin puting beliung di kedua provinsi tersebut kecil.

Manajemen bencana ialah upaya untuk menghindarkan masyarakat dari bencana, baik dengan mengurangi kemungkinan munculnya bahaya (hazard) maupun mengatasi kerentanan.Lingkaran manjemen bencana (disaster management cycle) terdiri atas 3 kegiatan dasar yaitu kegiatan sebelum terjadi bencana, saat terjadi bencana dan setelah terjadi bencana.Kegiatan yang dilakukan sebelum terjadi bencana dapat berupa pencegahan (prevention), kesiapsiagaan menghadapi bencana (preparedness) dan mengurangi dampak bencana (mitigation). Kegiatan saat terjadi bencana ialah tanggap bencana (response). Kegiatan setelah terjadi bencana dapat berupa pemulihan kembali pasca bencana (disaster recovery) yaitu rehabilitasi dan rekonstruksi. Ada tiga tahapan mendasar dalam manajemen bencana yaitu respon terhadap bencana, kesiapsiagaan menghadapi bencana dan minimalisasi (mitigasi) dampak bencana.Semua tahapan dilaksanakan secara bersama-sama dengan porsinya masing-masing agar berjalan dengan terarah.

Pencegahan (prevention) merupakan tahapan awal dari manajemen bencana yang dilakukan sebelum terjadi bencana.Pencegahan ialah upaya-upaya yang dilakukan untuk menghindari terjadinya bencana dan mencegah ancaman yang berpotensi menjadi bencana. Kegiatan pencegahan yang dapat dilakukan sebelum terjadi bencana angin ribut ialah pengaturan fungsi dan penggunaan lahan yang dapat memicu terjadinya gaya konvergensi. Kesiapsiagaan merupakan tahapan dalam manajemen bencana yang dilakukan sebelum terjadi bencana berupa upaya-upaya yang dilakukan untuk menghadapi dan mengantisipasi bencana. Kegiatan yang dilakukan pada tahapan kesiapsiagaan bencana angin ribut ialah simulasi tanggap bencana angin ribut, sistem peringatan dini (early warning system), penyiapan cadangan pangan dan obat-obatan, pembenukan dan peningkatan jumlah relawan tanggap bencana, jalur dan lokasi evakuasi.

Mitigasi bencana memiliki tujuan utama yaitu mengurangi risiko bencana yang dialami masayarakat.Mitigasi bencana merupakan istilah yang menunjukkan semua tindakan untuk mengurangi dampak dari suatu bencana yang dapat dilakukan sebelum bencana terjadi, termasuk kesiapan dan tindakan pengurangan risiko jangka panjang. Mitigasi bencana mencakup perencanaan dan pelaksanaan tindakan-tondakan pengurangan risiko bencana dan proses perencanaan respon efektif terhadap bencana yang akan terjadi. Tindakan pengurangan risiko jangka panjang dimaksudkan untuk meminimalisasi akibat-akibat yang merugikan dari suatu bencana.

Pada saat terjadi bencana, tahapan manajemen bencana yang dilakukan ialah tanggap darurat (response).Tanggap darurat ialah upaya-upaya yang dilakukan saat terjadi bencana untuk membantu korban agar kehilangan nyawa atau korban dapat diminimalisasi. Kegiatan tanggap darurat yang dapat dilakukan saat terjadi bencana angin 
ribut ialah pencarian korban dan evakuasi, pemenuhan kebutuhan dasar pangan, air bersih, layanan kesehatan, hunian sementara dan perlengkapan sanitasi serta perbaikan fasilitas penting seperti jembatan, tiang listrik dan pepohonan tumbang yang melintang di jalan.

\section{Kesimpulan}

Berdasarkan hasil analisis yang telah dilakukan, maka dapat disimpulkan beberapa hal berikut ini:

1. Berdasarkan peta distribusi bencana angin ribut, angin ribut banyak terjadi di beberapa provinsi yang ada di Pulau Jawa yaitu Provinsi Jawa Barat, Jawa Tengah dan Jawa Timur.Provinsi Jawa Tengah termasuk kedalam Kelas I (393 - 490 kejadian) sedangkan Provinsi Bengkulu dan Papua Barat tidak terjadi angin ribut (nol kejadian).

2. Bencana angin puting beliung mengakibatkan terjadinya kerusakan bangunan dan adanya korban jiwa baik luka-luka, meninggal maupun hilang. Jumlah kerusakan bangunan terbanyak akibat angin puting beliung tahun 1990-2011 terjadi di Provinsi Jawa Tengah, sedangkan jumlah korabn jiwa terbanyak terjadi di Provinsi Jawa Barat.

3. Upaya mitigasi yang dapat dilakukan untuk bencana angin ribut antara lain adalah membuat struktur bangunan yang mampu bertahan terhadap gaya angin, membuat bangunan umum yang cukup luas sebagai tempat evakuasi saat terjadi serangan angin ribut, pengamanan barang-barang di sekitar rumah agar terikat/ dibangun secara kuat sehingga tidak diterbangkan angin dan peningkatan kesiapsiagaan dalam menghadapi angin ribut dengan pengetahuan cara penyelamatan diri.

\section{Saran}

1. Perlu adanya penataan ruang di daerah permukiman padat (kota) untuk mengurangi atau meredam kecepatan angin dengan penghijauan.

2. Pembuatan peta-peta yang memuat daerah rawan bencana, dastribusi kejadian, jalur evakuasi, dan lokasi aman untuk pengungsian.

3. Publikasi kejadian bencana dan upaya mitigasi yang tepat pada daerah-daearah yang sering dilanda bencana.

4. Perlu adanya kegiatan peningkatan pemahaman dan peredaman risiko bencana kepada masyarakat serta simulasi bencana agar masyarakat menjadi tangguh dalam menghadapi bencana dan mampu mengelola risiko bencana dengan mandiri.

5. Pembentukan suatu organisasi pengurangan risiko bencana yang mantap dan terdukung oleh sumberdaya manusia yang handal serta penambahan komunitas relawan.

6. Perlu adanya koordinasi pendataan ke seluruh lapisan masyarakat hingga unit wilayah terkecil agar data jumlah korban dan kerusakan akibat bencana valid.

\section{Ucapan Terimakasih}

Tulisan ini merupakan hasil penelitian Insentif Penelitian Kolaborasi Dosen Mahasiswa tahun 2012 dengan judul yang sama. Penelitian ini dibiayai dari dana BOPTN UGM tahun 2012 sesuai Surat Tugas Pelaksanaan Kegiatan Nomor LPPM-UGM/350/BID.1/2012 tanggal 14 November 2012. 


\section{Daftar Pustaka}

Anonim. 2007. Undang-Undang Nomor 24 Tahun 2007 Tentang Penanggulangan Bencana. Jakarta: Lembaran NKRI Nomor 66.

Anonim. 2011. Alat Pengukuran Angin, Alpen Steel, http://www.alpensteel.com/article/47103-energi-angin--wind-turbine--wind-mill/2926--alat-pengukuran-angin.html diakses pada 29 April 2012.

Badan Pusat Statistik Indonesia. 2008. Statistik Indonesia 2008: Suhu maksimum, rata-rata, dan minimum di stasiun pengamatan BMKG $\left({ }^{\circ} \mathrm{C}\right), 2006$. Jakarta : BPS

Badan Pusat Statistik Indonesia. 2009. Statistik Indonesia 2009: Suhu maksimum, rata-rata, dan minimum di stasiun pengamatan BMKG ( $\left.{ }^{\circ} \mathrm{C}\right), 2007$. Jakarta : BPS

Badan Pusat Statistik Indonesia. 2010. Statistik Indonesia 2010: Suhu maksimum, rata-rata, dan minimum di stasiun pengamatan BMKG $\left({ }^{\circ} \mathrm{C}\right), 2008$. Jakarta : BPS

Badan Pusat Statistik Indonesia. 2006. Statistik Indonesia 2005/2006: Penduduk dan Laju Pertumbuhan Penduduk menurut Provinsi, 2000-2005. Jakarta : BPS

Budi, Muchus. 2012. Artikel DetikNews :Angin Ribut Terjang Surakarta, 1 Orang Tewas \& Ratusan Rumah Rusak, http://news.detik.com/read/2012/01/25/203556/1825105/10/angin-ribut-terjangsurakarta-1-orang-tewas-ratusan-rumah-rusak diakses pada 25 April 2012.

Badan Nasional Penanggulangan Bencana. 2012. Data : Jumlah Kejadian... Dari http://dibi.bnpb.go.id diakses pada 30 Oktober 2012

BNPB. 2012. Waspadai Bencana Angin Topan, http://bnpb.go.id/website/asp/content.asp?id=53 diakses pada 18 November 2012.

BNPB. 2012. Angin Topan, http://bnpb.go.id/website/asp/benc.asp?p=12 diakses pada 18 November 2012.

Fajri, Ahdi Ahmad. 2011Pola Kejadian Angin Puting Beliung di Provinsi Jawa Tengah dan Daerah Istimewa Yogyakarta.. Skripsi.Yogyakarta: Fakultas Geografi UGM.

Nirkaryanto. 1979. Angin Ribut di Jawa. Jakarta: Fipia Universitas Indonesia.

Polkamnas. 2012. Artikel Koran Jakarta :Puting Beliung Meningkat 2.781 Persen. http://koran-jakarta.com/index.php/detail/view01/88038 diakses pada 25 April 2012.

Prawirowardoyo, Susilo. 1996. Meteorologi. Bandung: Penerbit ITB.

Hidayah, Nurul. 2012. Artikel Republika.Com: Warga Cirebon dan Indramayu Diminta Waspadai Angin Kencang. Dari http://m.mediaindonesia.com diakses pada 22 November 2012

Siyono, E., Gunawan, Wahyu, Michele, Almaizon. 2012. Laporan Verifikasi Bencana Alam Banjir Bandang dan Tanah Longsor di Kabupaten Pasaman Propinsi Sumatera Barat Tahun 2012. Jakarta: Badan Nasional Penanggulangan Bencana.

Tjasyono, Bayong. 2004. Klimatologi. Bandung: Penerbit ITB.

Wahono, Tri. 2012. Artikel Kompas. Dua Bibit Badai Penyebab Angin Kencang di Berbagai Daerah. Dari http://sains.kompas.com/read/2012/01/25/16004127/Dua.Bibit.Badai .Penyebab.Angin.Kencang.di.Berbagai.Daerah diakses pada 25 April 2012. 
Kajian Bencana Angin Ribut di Indonesia Periode 1990-2011 : Upaya Mitigasi Bencana 